\title{
Flora da Paraíba, Brasil: Combretaceae
}

\author{
Maria Iracema Bezerra Loiola ${ }^{1}$ Emerson Antonio Rocha ${ }^{2}$, George Sidney Baracho ${ }^{3}$ e Maria de Fátima Agra ${ }^{4,5}$
}

Recebido em 27/08/2007. Aceito em 24/06/2008

\begin{abstract}
RESUMO - (Flora da Paraíba, Brasil: Combretaceae). Apresenta-se o tratamento taxonômico da família Combretaceae como parte do projeto "Flora da Paraíba", que vem sendo realizado com o objetivo de identificar e catalogar as espécies da flora local. As identificações, descrições e ilustrações botânicas foram efetuadas pela análise morfológica de amostras frescas e espécimes herborizados, com o auxílio da bibliografia e análise de tipos, complementadas pelas observações de campo. Foram registradas 11 espécies subordinadas a cinco gêneros: Buchenavia (1), Combretum (8), Conocarpus (1) e Laguncularia (1). Algumas espécies possuem distribuição restrita aos manguezais, como Conocarpus erectus L. e Laguncularia racemosa (L.) C.F. Gaertn., à Caatinga, como Combretum glaucocarpum Mart., C. leprosum Mart. e C. hilarianum D. Dietr., e a Floresta Atlântica, como Buchenavia tetraphylla (Aubl.) R.A. Howard, Combretum fruticosum (Loefl.) Stuntz e C. laxum Jacq.
\end{abstract}

Palavras-chave: Combreteae, Combretoideae, flora paraibana, Laguncularieae, Myrtales, Nordeste brasileiro

\begin{abstract}
Flora of Paraíba, Brazil: Solanum L., Solanaceae). This taxonomic treatment of the genus Solanum is part of the "Flora da Paraíba" project which aims to identify and catalogue the species of the local flora. Botanical collections, field observations and morphological studies were done for identification, description and botanical illustration of the plant species, also supported by the literature and analysis of Brazilian and foreign herbaria, plus specimens from EAN and JPB herbaria. Twenty two species of Solanum were recorded in the state of Paraíba: Solanum agrarium Sendtn., S. americanum Mill., S. asperum Rich., S. asterophorum Mart., S. caavurana Vell., S. capsicoides All., S. crinitum Lam., S. jabrense Agra \& M.Nee, S. melissarum Bohs, S. ovum-fringillae (Dunal) Bohs, S. palinacanthum Dunal, S. paludosum Moric., S. paniculatum L., S. paraibanum Agra, S. polytrichum Moric., S. rhytidoandrum Sendtn., Solanum sp., S. stagnale Moric., S. stipulaceum Roem. \& Schult., S. stramoniifolium Jacq., S. swartzianum Roem. \& Schult. and S. torvum Sw. Three species are new records for Paraíba: S. ovum-fringillae, Solanum sp. and S. swartzianum.
\end{abstract}

Key words: Flora of Paraíba, “Jurubeba”, Northeast Brazil

\section{Introdução}

A família Combretaceae possui cerca de 13 gêneros e 500 espécies, com distribuição tropical, ocorrendo em ambientes quentes de todos os continentes, com centros de diversidade na África e Ásia. Espécies da família constituem importantes elementos de mangues, florestas úmidas e de regiões semi-áridas (Stace 2004).

De acordo com Tan et al. (2002), Combretaceae tem sido tradicionalmente colocada na ordem Myrtales, desde que foi estabelecida por Robert Brown, em 1810, posição em que permaneceu nos sistemas de classificações posteriores, como os de Dahlgren \& Thorne (1984), Cronquist (1988), Tahktajan (1997) e o APG II (2003). Este posicionamento tem sido sustentado pelos estudos moleculares mais recentes (Conti et al.
1996; 1997). Para Stace (2004), os estudos morfológicos e moleculares apóiam Combretaceae como um grupo monofilético, próximo de Lythraceae.

Com relação à classificação da família, desde Engler \& Diels (1899) duas subfamílias têm sido reconhecidas para Combretaceae, Strephonematoideae e Combretoideae (Tan et al. 2002), e empregadas nos tratamentos mais atuais para a família (Exell \& Stace 1966; Stace 2004). De acordo com Stace (2004), a subfamília Strephonematoideae possui um único gênero, Strephonema, com distribuição exclusiva na África, e a subfamília Combretoideae possui o maior número de espécies e a distribuição mais ampla, com duas tribos, Laguncularieae e Combreteae, com quatro e doze gêneros, respectivamente, sendo os gêneros Combretum e Terminalia encontrados em todos os continentes.

\footnotetext{
1 Universidade Federal do Rio Grande do Norte, Departamento de Botânica, Ecologia e Zoologia, CB, Campus Universitário, 59072-970 Natal, RN, Brasil

2 Universidade Estadual de Santa Cruz, Departamento de Ciências Biológicas, Pavilhão Jorge Amado, Rodovia Ilhéus-Itabuna km 16, 45650-000 Ilhéus, BA, Brasil

3 Universidade de Pernambuco, Instituto de Ciências Biológicas, Departamento de Biologia, Laboratório de Biologia Vegetal, 50100-130 Recife, PE, Brasil

4 Universidade Federal da Paraiba, Setor de Botânica, Laboratório de Tecnologia Farmacêutica, C. Postal 5009, 58 051-970 João Pessoa, PB, Brasil

5 Autor para correspondência: agramf@ltf.ufpb.br
} 
A complexidade taxonômica e filogenética da subfamília Combretoideae é reconhecida pela maioria dos autores, principalmente pela ampla variação morfológica nas flores, frutos e brotos vegetativos, de acordo com Tan et al. (2002). Para o autor, a classificação da subfamília tem sido bastante controvertida nos vários tratamentos propostos (Bentham \& Hooker 1867; Brandis 1898; Engler \& Diels 1899; Exell 1931; 1953; Exell \& Stace 1966). Os estudos moleculares mais recentes (Conti et al. 1996; 1997), têm apoiado a classificação morfológica tradicional de Combretaceae e a monofilia da tribo Combreteae, sensu Engler e Diels (1899), incluindo os gêneros Quisqualis e Combretum.

Espécies de Combretaceae não se destacam pelo valor econômico; poucas são cultivadas como ornamentais, Quisqualis indica L. e Terminalia catappa, por exemplo. Algumas são referidas pelo seu emprego na medicina popular (Braga 1960; Agra 1996; Fyhrquist et al. 2002) ou potencial farmacológico (Férrea et al. 1993; Baba-Mossa et al. 1999). As sementes dos frutos de Terminalia cattapa (castanhola ou amêndoa-indiana) são oleaginosas e empregadas como alimento na Índia (Stace 2004).

O tratamento mais completo para Combretaceae no Brasil foi realizado por Eichler (1867), que reconheceu nove gêneros e 65 espécies. A partir de então, poucos trabalhos foram publicados, alguns em floras (Marquete et al. 2003; Marquete \& Valente 2006), porém a maioria envolvendo descrições de novos taxa (Engler \& Diels 1899; Fawcett \& Rendle 1925) e novas combinações (Exell 1931; 1953; Exell \& Stace 1966). Entretanto, de acordo com Marquete \& Valente (2006), atualmente estima-se a ocorrência de 78 espécies subordinadas a seis gêneros no país.

No nordeste do Brasil, representantes de Combretaceae foram citados em trabalhos pontuais, como floras e listas regionais, dentre os quais se destacam o de Zappi (1995), para a Bahia, com o registro de duas espécies de Terminalia; Loiola \& Sales (1996) e Loiola (1998), referiram nove e três espécies, respectivamente, para Pernambuco; Giulietti et al. (2002), indicaram três espécies como endêmicas para a Caatinga; mais recentemente, Marquete \& Valente (2006) relacionaram uma lista de 12 espécies para a região.

Para a Paraíba, as informações existentes para a família são pontuais, com apenas duas espécies referidas em levantamentos florísticos e trabalhos etnobotânicos. Andrade-Lima \& Rocha (1971) e Barbosa et al. (2004) referiram a ocorrência de Buchenavia capitata para a Mata do Buraquinho, no litoral, e para a Mata de Pau-ferro, em Brejo de Altitude, respectivamente; Agra et al. (2004) registraram a presença de Combretum leprosum no Pico do Jabre, uma área de mata serrana.
Além disso, Agra (1996) e Agra et al. (2007) referiram os usos etnomedicinais desta espécie para a microrregião do Cariri Paraibano.

O presente trabalho teve como objetivo o tratamento taxonômico da família Combretaceae no Estado da Paraíba, contribuindo para um maior conhecimento do grupo e também da diversidade da flora local, dando continuidade ao Projeto Flora da Paraíba (Cabral \& Agra 1999; Rocha \& Agra 2001; Pontes et al. 2004; Pontes \& Agra 2005; Nurit et al. 2005; Loiola et al. 2007; Coelho et al. 2008).

\section{Material e métodos}

Realizaram-se coletas e observações de campo, relativas à morfologia, fenologia e ecologia, em diversas regiões do Estado. Para as identificações, descrições e ilustrações botânicas foram realizados estudos morfológicos de amostras frescas e espécimes dos herbários EAC, EAN, JPB, IPA, PEUFR, RB, SP, SPSF e UB, com auxílio da bibliografia especializada (Eichler 1867; Exell \& Stace 1966; Stace 1968, 2001; Marquete 1995; Loiola \& Sales 1996; 1998), complementados pela análise de tipos e fotos de tipos dos herbários F, NY, e observações de campo. Os acrônimos dos herbários estão de acordo com Holmgren et al. (1990). A classificação da vegetação está de acordo com Carvalho \& Carvalho (1985).

As informações sobre o hábito das plantas, cor das flores e frutos, fenologia, distribuição geográfica e nome popular foram obtidos dos rótulos das exsicatas consultadas e observações de campo, quando necessário, complementadas com dados da literatura. As análises morfológicas e as pranchas ilustrativas foram realizadas com o auxílio de estéreo-microscópio e câmara-clara. O tratamento taxonômico seguiu o modelo proposto para a Flora da Paraíba (Nurit et al. 2005). A terminologia dos frutos segue Barroso et al. (1999). As abreviaturas dos autores dos táxons estão de acordo com Brummitt \& Powell (1992) e a terminologia adotada para designar as formas das estruturas foi baseada em Stearn (1992). A delimitação de Combretum está de acordo com Stace (2004), incluindo Thiloa.

\section{Resultados e discussão}

Combretaceae R. Br., Prodr. 351. 1810.

Ervas, arbustos escandentes e árvores, heliófilas, xerófilas a halófitas, inermes, raro espinhosas; plantas hermafroditas, andromonóicas ou raramente dióicas. Folhas opostas, alternas, espiraladas ou verticiladas, simples, pecioladas, sem estípulas; lâmina membranácea, 
cartácea, subcoriácea ou coriácea, inteira, peninérvea, elíptica, obelíptica, ovada, obovada, oblanceolada, lanceolada ou oblonga, glabrescente a cinéreopubescente, com ou sem tricomas glandulares ou escamosos, peltados ou subsésseis, às vezes com nectários extraflorais. Inflorescências axilares ou terminais, espigas, panículas de espigas, capítulos, ou raramente racemos subcapitados, com o mesmo padrão de tricomas das folhas. Flores 4-5-meras, actinomorfas ou raramente zigomorfas, epíginas ou raramente semiepíginas, monoclamídeas ou diclamídeas. Hipanto envolvendo o ovário, expandido para a parte superior. Lobos do cálice 4-5, simétricos, dispostos no ápice do hipanto superior, livres ou soldadas. Pétalas 4-5, quando presentes, alternissépalas, alvo-esverdeadas, amarelas ou avermelhadas, actinomorfas, livres; prefloração valvar ou imbricada. Estames 4-10, raro ausentes, representados por estaminódios, exsertos ou inclusos; filetes cilíndricos; anteras ditecas, dorsifixas, versáteis, raro adnatas, com deiscência rimosa. Disco nectarífero geralmente na base do hipanto superior. Ovário ínfero, unilocular; 2-6 óvulos, apicais, com placentação pêndula; estilete cilíndrico, geralmente filiforme sobre o disco nectarífero; estigma punctiforme, inconspícuo. Fruto geralmente indeiscente, seco ou suculento, drupóide, nucóide ou betulídeo, 2-5 alas papiráceas a coriáceas, enrugadas; semente 1, endosperma ausente, embrião axial, ereto, cotilédones 2 (3), às vezes fusionados, variadamente plicados ou convolutos.

Para a Paraíba foram registradas 11 espécies subordinadas a cinco gêneros: Buchenavia tetraphylla (Aubl.) R. A. Howard, Combretum duarteanum Cambess., C. fruticosum (Loefl.) Stuntz, C. glaucocarpum Mart., C. hilarianum D. Dietr., C. lanceolatum Eichler, C. laxum Jacq., C. leprosum Mart., C. pisonioides Taub., Conocarpus erectus L. e Laguncularia racemosa (L.) C.F. Gaertn.. A maioria das espécies possui distribuição restrita, algumas ocorrem em manguezais, outras em ambientes de Caatinga ou em área de Floresta Atlântica.

Chave para os gêneros de Combretaceae no Estado da Paraíba, Brasil

1. Folhas opostas; inflorescências em panículas, racemos ou espigas; pétalas ausentes ou presentes; fruto nucóide ou betulídio

2. Arbustos ou árvores de mangues; folhas com duas glândulas de sal no pecíolo; flores com pétalas; frutos nucóides

4. Laguncularia

2. Lianas, arbustos escandentes ou árvores de outros ambientes; folhas sem glândulas de sal no pecíolo; flores com ou sem pétalas; frutos betulídios, 4-alados

2. Combretum

1. Folhas alternas, espiraladas ou rosuladas; inflorescências em capítulos; pétalas ausentes; frutos drupóides ou agregados em infrutescências globosas

3. Arbustos ou árvores de mangue; folhas com glândulas no pecíolo ou na base da lâmina; inflorescências em racemos ou panículas de capítulos globosos; estames 8, exsertos, dispostos em um verticilo; frutos agregados, formando uma infrutescência globosa, estrobiliforme

3. Conocarpus

3. Árvores de outros ambientes; folhas sem glândulas na base do pecíolo; flores em capítulos; estames 10, insertos, dispostos em dois verticilos; frutos livres entre si, drupóides, levemente costados

1. Buchenavia

1. Buchenavia Eichler, Flora 49(11): 164. 1866.

1.1. Buchenavia tetraphylla (Aubl.) R.A. Howard, J. Arnold Arbor. 64(2): 266. 1983.

Fig. 1-4

Árvores até $15 \mathrm{~m}$ alt.; ramos acinzentados, estriados. Folhas espiraladas ou rosuladas, concentradas no ápice dos ramos, pecioladas; pecíolo 4-5 $\mathrm{mm}$ compr., sem glândulas na base; lâmina 3-4,5×1,4-2,2 cm, obovada, oblonga a oblanceolada, base cuneado-atenuada, ápice arredondado, emarginado ou truncado, mucronulado, glabra, coriácea, brilhante, nervuras proeminentes em ambas as faces. Inflorescências axilares ou terminais, em capítulos densifloros, 0,8-1,2 cm compr.; pedúnculo
1,4-2,1 cm compr.; flores monoclinas, $0,2-0,3 \mathrm{~cm}$, esverdeadas; hipanto inferior 1,3-1,7×0,4-0,5 mm, cilíndrico, espessado na base, densamente pubescente; hipanto superior $0,7-0,8 \times 1,7-2 \mathrm{~mm}$; lobos do cálice inconspícuos, pétalas ausentes. Estames 10, exsertos; filetes espessados, os do verticilo interno $3-3,5 \mathrm{~mm}$, os do verticilo externo 3,5-4 mm; anteras $0,2-0,3 \times$ 0,2-0,3 mm, cordiformes. Disco nectarífero piloso, ferrugíneo; estilete 0,6-0,8 mm compr. Fruto drupóide, 1,6-1,8×0,7-0,9 cm, oval-elíptico, pontiagudo no ápice, glabro, levemente costado, geralmente enegrecido quando maduro. Sementes não vistas.

Nomes populares: berindiba, merindiba, imbiridiba e embiridiba. 
De acordo com Weaver (1991), Buchenavia tetraphylla é uma espécie neotropical, com distribuição natural desde a ilha de Cuba até o Rio de Janeiro, no Brasil. Na Paraíba a espécie foi encontrada em remanescentes de Floresta Atlântica, no litoral e em uma área de Brejo de Altitude, e em áreas de tabuleiros.

Material examinado: BRASIL. Paraíba: Areia, Chã de Jardim, II/1954, est., Carneiro s.n. (JPB 1840); Cabedelo, Camboinha, XII/1969, fl., Xavier s.n. (JPB 2734); João Pessoa, Falésia do Cabo Branco, XII/1986, fl., Miranda 211 (JPB); Faz. Mangabeira, I/1994, fl., Moura 1174 (JPB); Campus I UFPB, I/1995, fl., Gadelha Neto 216 (JPB); V/1995, fr., Gadelha Neto s.n. (JPB 23373); Santa Rita, Usina São João, $7^{\circ} 57^{\prime}$ 'S-3500, 30 m, 4/IV/1992, fr., Agra et al. 1444 (JPB); Mamanguape, tabuleiros, 31/V/1959, est., Moraes s.n. (EAN 3739).

2. Combretum Loefl., Iter Hispan. App. 308. 1758.

Thiloa Eichler, Flora 49(10): 149. 1866.

Chave para as espécies de Combretum na Paraíba, Brasil

1. Flores apétalas; estames 4, inclusos

3. C. glaucocarpum

1. Flores com pétalas; estames 8, exsertos

2. Flores acima de $20 \mathrm{~mm}$ de compr.; fruto com apículo na porção superior da região central

3. Pétalas suborbiculares a orbiculares; hipanto superior crateriforme; disco nectarífero protuberante, cônico, envolvendo o estilete; tricomas escamosos, hialinos, com o centro amarelo ou amarelo-claro

5. C. lanceolatum

3. Pétalas elípticas; hipanto superior infundibuliforme-campanulado; disco nectarífero em forma

de anel, contínuo; tricomas escamosos, ferrugíneos

2. C. fruticosum

2. Flores até $15 \mathrm{~mm}$ de compr.; fruto desprovido de apículo na porção superior da região central

4. Ramos e folhas viloso-seríceos a laxo-lepidotos, tricomas simples e escamosos, esparsos

4. C. hilarianum

4. Ramos e folhas exclusivamente lepidotos, tricomas escamosos

5. Pétalas suborbiculares a reniformes, arredondadas a oblatas

6. Inflorescências em panículas laxas; disco nectarífero inconspícuo, margem subglabra a glabra; pétalas suborbiculares a reniformes; fruto com alas reduzidas

6. C. laxum

6. Inflorescências em panículas densas; disco nectarífero desenvolvido, margem vilosa; pétalas arredondadas a oblatas; fruto com alas desenvolvidas

7. C. leprosum

5. Pétalas obovadas a espatuladas

7. Bractéolas espatuladas; fruto anfractuoso-plicado, alas bastante reduzidas, sinuosas

1. C. duarteanum

7. Bractéolas estreito-lineares a lineares; frutos elípticos a largamente elípticos, alas desenvolvidas, planas

8. C. pisonioides

2.1. Combretum duarteanum Cambess., in A.St.-Hil.,

Fl. Bras. Merid. 11: 248. 1829.

Fig. 5-7

Arbustos eretos a escandentes, até 1,5 m de alt.; caule e ramos estriados, cinéreos, toda planta lepidota, tricomas escamosos, hialinos ou ferrugíneos, revestindo o caule, ramos, folhas, botões e frutos. Folhas opostas, curto-pecioladas; pecíolos 1-2 mm compr.; lâminas 4,8-10× 3-6,5 cm, membranáceas, glabras, elípticas ou obelípticas, base aguda, ápice acuminado a caudado, raro cuspidado, concolor, ambas as faces opacas; nervuras proeminentes na face inferior. Inflorescência em racemo subcapitado, axilar; raque 3,5-7,5 cm compr.; botão 2-3 mm compr., turbinado. Flores $8-9 \mathrm{~mm}$ compr., esverdeadas; bractéola 1, 1-2 mm compr., espatulada com ápice acuminado; hipanto inferior 1,5-2x 0,5-0,7 $\mathrm{mm}$, fusiforme a levemente anguloso; hipanto superior 2-2,5×2,5-3 mm, infundibuliforme na base e cupuliforme no ápice; lobos do cálice 4, 1,5-2× 1-1,5 mm, deltóides; pétalas 4, 1,5-2×0,5-1 mm, obovadas a espatuladas, maiores que os lobos do cálice, amarelo-claro na antese e vermelhas na pós-antese. Estames 8, exsertos; filetes do verticilo interno 3-3,5 mm, filetes do verticilo externo 3,5-4 $\mathrm{mm}$; anteras 0,4-0,6×0,4-0,5 mm, elípticas, alaranjadas. Disco nectarífero com margem livre, densamente viloso na porção de inserção dos filetes; estilete 3,5-4 mm compr. Fruto 4-alado, 10-27(-30,0)×10-12 mm, anfractuosoplicado, desprovido de apículo na porção superior da região central; alas 4-5 mm larg., sinuosas, bastante 
reduzidas; pedicelo frutífero $1,5-2 \mathrm{~mm}$ compr. Semente 1, 1,5-1,8×0,3-0,4 cm, estreita-elipsóide, sulcada longitudinalmente, testa coriácea, enrugada, castanhoclara, cotilédones foliáceos.

Nomes populares: mofumbo, cipiúba e cipaúba.

Espécie exclusiva da América do Sul, com registro na Bolívia, Paraguai e Brasil (Exell 1953). Segundo Loiola \& Sales (1996), ocorre no Brasil nas regiões Norte (Pará), Nordeste (Bahia, Ceará, Maranhão, Paraíba, Pernambuco e Piauí), Centro-Oeste (Distrito Federal, Goiás e Mato Grosso) e sudeste (Minas Gerais e São Paulo). A presença desta espécie associada a ambientes de caatinga foi reportada para os estados da Bahia, Paraíba e Pernambuco (Loiola \& Sales 1996). Sua ocorrência na Paraíba está restrita à Caatinga, encontrada geralmente em afloramentos rochosos.

Material selecionado: BRASIL. Paraíba: Alagoinha, Estação Experimental, IX/1942, fl., Xavier s.n. (JPB 975); Areia, serra da Onça, II/1992, fl., Félix 4737 (EAN); Itaporanga, $37 \mathrm{~km}$ depois de Itaporanga, em direção à Conceição, XI/1971, fl., Andrade-Lima 1087 (IPA); Cabaceiras, Lajedo Pai Mateus, VI/2003, fl. fr., Coelho et al. s.n. (JPB 36244); Itapororoca, Fazenda Macacos, I/1987, fl., Félix \& Dornelas 1476 (EAN); Pirpirituba, II/1959, fl., Moraes 2043 (EAN, RB); São Gonçalo, Posto Agrícola de S. Gonçalo, I/1936, fl., Luetzelburg s.n. (IPA 8932); Marizopólis, Rio Matumba, I/1936, fl., Luetzelburg 26826 (NY); Serra Branca, Serra do Jatobá, IV/2006, Gadelha Neto \& Pontes 1508 (JPB); 13-15/III/2007, fl., Agra et al. 6767 (JPB); 13-15/III/2007, fr., Agra et al. 6792 (JPB); Sousa, Fazenda Jangada, III/1995, fl., Gadelha Neto 171 (JPB); serrote do Letreiro, I/1998, fl., Gadelha Neto 380 (JPB).

2.2. Combretum fruticosum (Loefl.) Stuntz, U.S.D.A.

Bur. Pl. Industr. Invent. Seeds 31: 86-87. 1914.

Fig. 8-9

Arbustos ou lianas, até $3 \mathrm{~m}$ de alt.; caule e ramos castanho-avermelhados, indumento lepidoto-ferrugíneo revestindo o caule, ramos, folhas, botões e frutos. Folhas opostas, pecioladas; pecíolo 7-10 mm compr.; lâmina 8,5-12,5×3,9-7,5 cm, coriácea, glabra, estreito-elíptica a elíptica, base aguda, ápice acuminado a arredondado, discolor; face adaxial verde mais escuro, face abaxial verde-clara; nervuras mais proeminentes na face inferior. Inflorescências em racemos alongados, densifloros, axilares e terminais; raque dos racemos $5,8-14 \mathrm{~cm}$ compr.; botões 9-10 mm compr., turbinados. Flores subsésseis 22-28 mm compr., esverdeadas a avermelhadas; bractéola 1, com 1-2 mm compr., estreitoespatulada; hipanto inferior 2-3×0,4-0,5 mm, fusiforme a 4- anguloso; hipanto superior $6-7 \times 4-4,5 \mathrm{~mm}$, infundibuliforme-campanulado; lobos do cálice 4 ,
1-2×1,5-2 mm, deltóides, avermelhados; pétalas 4 , 1-1,5×0,4-0,5 mm, elípticas, menores que os lobos do cálice, amarelas. Estames 8, exsertos; filetes do verticilo interno $12-13 \mathrm{~mm}$, filetes do verticilo externo $13-14 \mathrm{~mm}$; anteras $0,4-0,5 \times 0,4-0,5 \mathrm{~mm}$, elípticas, alaranjadas a avermelhadas. Disco nectarífero conspícuo, em forma de anel contínuo, margem livre e densamente vilosa; estilete 1,3-1,4 cm compr. Fruto 4-alado, 1,34-1,9×1,1-1,4 mm, elipsóide, com apículo na porção superior da região central, avermelhado quando jovem, alas 4-6 mm larg., delgadas, secas, transversalmente estriadas; pedicelo frutífero $1,5-3 \mathrm{~mm}$ compr. Semente 1, 15-18×3,5-4 mm, estreito-elipsóide, sulcada longitudinalmente, testa coriácea, enrugada, castanho claro, cotilédones foliáceos.

Nomes populares: pente-de-macaco e mofumbo.

Combretum fruticosum é uma espécie neotropical, com ampla distribuição, ocorrendo desde o México até a Argentina, incluindo as Antilhas (Exell 1953). Embora habite preferencialmente os ambientes de florestas úmidas, esta espécie foi encontrada em todas as regiões brasileiras, compondo os mais variados tipos de vegetação, em praticamente todos os Estados (Loiola \& Sales, 1996). Na Paraíba, C. fruticosum foi encontrada em remanescentes de Floresta Atlântica e em áreas de Caatinga.

Material examinado: BRASIL. Paraíba: Araruna, VII/2003, fl., Pitrezi 456 (EAN); Areia, serra da Onça, II/1992, fl., Félix 4729 (EAN); orla de mata, X/1942, fl., Moraes s.n. (EAN 16, SPSF); VII/1945, fl., Moraes 434 (EAN, SPSF, RB, UB); VII/1953, fl., Moraes s.n. (EAN); X/1958, fl., Moraes s.n. (EAN); Gurinhém, VIII/1972, fl., Carvalheira s.n. (JPB 3336); Itapororoca, lagoa do Saco, X/1987, fl., Félix \& Dornelas 1527 (EAN); Mataraca, IX/1993, fl., Moura 1082 (JPB); Santa Rita, Engenho São Bento, VIII/1972, fl., Carvalheira s.n. (JPB 3289); Usina São João, Tibirizinho, X/1995, fl., Agra et al. 3459, 3467, 3468 (JPB); Sapé, VIII/1979, fl., Agra 146 (JPB).

2.3. Combretum glaucocarpum Mart., Flora 24(2): 3. 1841.

Thiloa glaucocarpa (Mart.) Eichler

Fig. 10

Árvore ereta, até $8 \mathrm{~m}$ alt.; caule e ramos glabros ou lepidotos, com tricomas escamosos, esparsos, nos ramos, folhas, flores e frutos. Folhas opostas, pecioladas; pecíolo 5-10 mm compr., sem glândulas nectaríferas; lâmina 5-12×2,5-6 cm, cartácea a coriácea, elíptica a largamente elíptica, ápice acuminado ou agudo, base arredondada ou cuneada, levemente discolor, verde e glauca adaxialmente, cinérea abaxialmente, margem inteira a crenulada. Inflorescências axilares e terminais, 
em panículas congestas; raque dos racemos 3,5-5,8 cm compr., cilíndrica, lepidota, ferrugínea; botões globosos 1,7-2 mm diâm., ferrugíneos; bractéola 1, dentiformesubulada, 4-6 mm compr., na base do hipanto inferior. Flores monoclinas, 4-4,5 mm compr., fusco-ferrugíneas; hipanto inferior 1,5-2,2 $\mathrm{mm}$ compr.; hipanto superior 1,5-2×2-2,4 mm, cupuliforme, densamente lepidoto fusco-ferrugíneo externamente, glabro a esparsamente pubescente, internamente; lobos do cálice ausentes ou curtíssimos, dentiformes, menores que $0,5 \mathrm{~mm}$ compr., pubescentes externamente; pétalas ausentes. Estames 4, insertos, do mesmo tamanho ou menor que o hipanto superior; filetes 1,8-2 mm compr.; anteras cordiformes, 0,4-0,5 mm, versáteis. Disco nectarífero espessado nas margens, viloso; estilete 2,8-3- mm compr. Fruto betulídio, 4-alado, 1,4-2,6×1,4-1,9 cm, coriáceo ou lenhoso, indeiscente, elipsóide, provido de apículo na porção superior da região central, alas escariosas, transverso-estrioladas, delgadas, dispostas em cruz. Semente solitária, >1 cm compr., oblonga, 4-sulcada longitudinalmente, cotilédones irregulares.

De acordo com Stace (1968), é uma espécie neotropical, exclusiva da América do Sul, referida pelo autor como exclusiva do Brasil, encontrada nos Estados do Acre, Pará, Piaú, Ceará, Bahia e Minas Gerais. Na Paraíba é uma espécie rara, só conhecida de uma coleta realizada em uma área de mata serrana, na Caatinga, sendo aqui referida pela primeira vez para o Estado.

Material examinado: BRASIL. Paraíba: Monte Horebe, Sítio Pinga de Baixo, III/2000, fl., Barbosa et al. 2067 (JPB).

\subsection{Combretum hilarianum D. Dietr., Syn. Pl. 2: 1303. 1840.}

Fig. 11-12

Arbustos eretos ou lianas, até $1,8 \mathrm{~m}$ de alt., indumento viloso-seríceo a laxo-lepidoto, amarelado a ferrugíneo, com tricomas simples, abundantes, e escamosos, esparsos, no caule, ramos, folhas, botões e flores. Caule e ramos vináceos quando jovens, cinéreos na planta adulta. Folhas opostas, curto-pecioladas; pecíolo 2-3 mm compr.; lâmina foliar 4-7,5×1,8-3,5 cm, elíptica a lanceolada, base obtusa a levemente cordada, ápice agudo a caudado; nervuras proeminentes na face abaxial, levemente discolor; vilosa, serícea e lepidota na face adaxial, denso-vilosa, laxo-lepidota na abaxial. Inflorescências em panículas de espigas duplas, densifloras, axilares e terminais; raque das espigas 3,5-8,5 cm compr.; botões $3-4 \mathrm{~mm}$ compr., arredondados. Flores 6-8 mm compr., esverdeadas; bractéola 1, com 1-1,5 mm compr., elíptica a oblongoelíptica, tomentosa em ambas as faces; hipanto inferior 1,5-2 $\times 2,5-3 \mathrm{~mm}$, fusiforme; hipanto superior
1-1,5×2,5-3 mm, raso-cupuliforme; lobos do cálice 4, 0,5-1×1-1,5 mm, deltóides; pétalas 4, 1-1,5×0,8-1 mm, obovado-espatuladas, seríceas, menores que os lobos do cálice, amarelas. Estames 8, exsertos, alvacentos; filetes do verticilo interno $3,8-4,5 \mathrm{~mm}$ e filetes do verticilo externo 4-5 mm; anteras 0,5-0,8×0,5-0,6 mm, cordadoelípticas, alvacentas a amareladas. Disco nectarífero em forma de anel, margem livre, densamente vilosa; estilete 2-3,5 mm compr. Fruto betulídio, 4-alado, 1,1-1,5×0,9-1,2 cm, cordado-orbicular, desprovido de apículo na porção superior da região central, vináceo quando jovem e castanho na maturidade, alas 4,5-5,5 mm larg., membranáceas, transversalmente estriadas; pedicelo frutífero 1-1,5 mm compr., ampliado. Semente 1, 1,5-1,8×0,3-0,4 cm, estreito-elipsóide, sulcada longitudinalmente, testa coriácea, enrugada, castanho claro, cotilédones foliáceos.

Espécie neotropical com ocorrência restrita ao Peru e Brasil, de acordo com Exell (1953). Em território brasileiro ocorre principalmente no extremo norte (Acre, Piauí, Ceará, Pernambuco, Paraíba, Bahia, Distrito Federal) até Minas Gerais, em ambientes de mata decídua e de Caatinga, estando geralmente relacionada a áreas com vegetação alterada (Loiola \& Sales 1996). Na Paraíba, esta espécie tem sido pouco coletada e suas populações habitam preferencialmente os ambientes de Caatinga. Apenas uma coleta está registrada para uma área de Brejo de Altitude.

Material examinado: BRASIL. Paraíba: Areia, V/1978, fl., Andrade-Lima 78-8432 (IPA); São José dos Cordeiros, RPPM - Fazenda Almas, trilha para a parcela, VI/2003, fr., Lima et al. 124 (JPB); Massaranduba, Distrito de Serra Redonda, 3/II/1959, fl., Moraes 03 (EAN).

2.5. Combretum lanceolatum Eichler, Fl. Bras. 4(2): 110, pl. 28, 34, f. 4.1867.

Fig. 13-15

Arbustos escandentes, ocasionalmente volúveis, até $4 \mathrm{~m}$ de alt., indumento lepidoto, hialino, canescente a amarelado, revestindo o caule, ramos, folhas, botões, flores e frutos; ramos estriados, castanhos. Folhas opostas; pecíolo 2-8 $\mathrm{mm}$ compr.; lâmina foliar 7-10×2,8-4,5 cm, estreito-elíptica a elíptica, base aguda, ápice agudo a acuminado, subcoriácea, discolor; face adaxial verde mais intenso, levemente brilhante, face abaxial verde-clara, opaca; nervuras impressas na face superior e proeminentes na inferior. Inflorescências em panículas de racemos, densifloras, congestas, axilares e/ou terminais; raque dos racemos 6,5-19 cm compr.; botões ca. $10 \mathrm{~mm}$ compr., turbinados. Flores subsésseis 2,2-3,6 cm compr., esverdeadas a amareladas; bractéola 1, 8-14 mm compr., obovada a espatulada, caduca ou 
persistente; hipanto inferior 5-6×1,3-1,7 mm, tetrágono; hipanto superior $6-7 \times 7-8 \mathrm{~mm}$, crateriforme, externamente lepidoto e internamente pubescente; cálice 4-lobado, lobos 1,8-2×2,7-3 mm, deltóides; pétalas 4, 1-1,5×1,5-2 mm, suborbiculares a orbiculares, menores que os lobos do cálice, amarelo-claras. Estames 8, exsertos; filetes do verticilo interno 2,1-2,2 cm compr. e filetes do verticilo externo 2,3-2,5 cm compr., esverdeados; anteras 1,5-2×1-1,3 mm, elípticas, alaranjadas. Disco nectarífero protuberante, velutino, envolvendo o estilete, margem livre; estilete $2,6-2,8 \mathrm{~cm}$ compr.. Fruto 4-alado, 2-2,3×1-1,4 cm, elipsóide, vináceo quando jovem e castanho na maturidade, ápice obcordado, apiculado; alas 5-6 mm larg., secas, transversalmente estriadas; pedicelo frutífero $2-4 \mathrm{~mm}$ compr. Semente 1, 1,5-1,8×0,3-0,4 cm, estreitoelipsóide, sulcada longitudinalmente, testa coriácea, enrugada, castanho clara, cotilédones foliáceos.

Nomes populares: mofumbo-de-beira-de-rio, mofumbo-preto e mofumbo-d'água.

Combretum lanceolatum é uma espécie neotropical, com distribuição exclusiva na América do Sul, encontrada no Paraguai e Brasil (Exell 1953). De acordo com Loiola \& Sales (1996), a espécie ocorre no Brasil nas regiões Norte (Pará), Centro-Oeste (Distrito Federal, Goiás e Mato Grosso) e Nordeste, onde é melhor representada (Alagoas, Bahia, Ceará, Maranhão, Paraíba, Pernambuco, Piauí e Rio Grande do Norte). Além desses estados ainda foi citada para o Rio de Janeiro por Exell (1953). Na Paraíba, a espécie foi encontrada apenas em áreas de Caatinga.

Material examinado: BRASIL. Paraíba: Sem local preciso, II/1959, Moraes 2040 (EAN, NY); Antenor Navarro, brejo das Freiras, VII/1974, fl., Xavier s.n. (JPB); Cajazeiras, VII/1978, fl., Agra \& Xavier (JPB); Piancó, Emas, IX/1972, fl., R. Cavalheira s.n. (JPB 3349); Pombal, VII/1984, fl., Ataide 512 (PEUFR); margem estrada de Pombal a Catolé, VII/1984, fl., Ataide 537 (IPA); Santa Cruz, Faz. Catolé, VII/1982, fl., Sousa et al. 1295 (JPB); São Gonçalo, Posto Agrícola de S. Gonçalo, III/1936, fl., fr., Luetzelburg s.n. (IPA 3501); Sousa, Faz. Jangada, VIII/1993, fl., Gadelha Neto 65 (JPB); Sítio Lamarão, IX/1994, fl., Moreira 06 (JPB); Faz. Jangada, VIII/1997, fl., Gadelha Neto 368 (JPB); Vale dos Dinossauros, I/1998, fl., Gadelha Neto 373 (JPB).

2.6. Combretum laxum Jacq., Enum. Syst. Pl. 19. 1760. Fig. 16-19

Arbustos escandentes ou lianas, até 3,5 m de alt.; indumento lepidoto, canescente, tricomas escamosos peltados, revestindo folhas, flores e frutos, esparsamente vilosos, amarronzados nas folhas e flores. Folhas opostas; pecíolo 5-8 mm compr.; lâmina 4-13×2,8-6 cm, coriácea, largo-oblonga a oval-elíptica, base obtusa, arredondada a subcordada, ápice agudo, arredondado a emarginado, nervuras proeminentes na face abaxial, impressas na adaxial. Inflorescências em panículas de espigas laxas, dispostas aos pares, formando panículas, terminais e axilares; raque principal 10-32 cm compr.; raque das espigas 2,5-8 cm compr.; botões 1-2 mm compr., capitados. Flores 6-7 mm compr.; bractéola 1, ca. $1 \mathrm{~mm}$ compr., linear, lepidota; hipanto inferior 1-1,5x 0,5-0,7 mm, fusiforme, indumento viloso-lepidoto, esparso, entre os tricomas escamosos; hipanto superior 0,7-1 $\times 1,5-2 \mathrm{~mm}$, pateliforme a cupuliforme; lobos do cálice ca. de 0,5 mm compr.; pétalas 4, 0,5-1×1-1,5 mm, suborbiculares a reniformes, maiores que os lobos do cálice, glabras, amarelo-claras. Estames 8, exsertos; filetes do verticilo interno $3,2-3,6 \mathrm{~mm}$ compr., filetes do verticilo externo $4-4,5 \mathrm{~mm}$ compr.; anteras 0,4-0,5×0,5-0,6 mm, elípticas, alaranjadas. Disco nectarífero pouco desenvolvido, margem subglobosa, glabrescente a glabra; estilete 3,8-4,2 $\mathrm{mm}$ de compr. Fruto 4-alado, 1,7-2,1×0,9-1,1 cm, elipsóide, desprovido de apículo na porção superior da região central, ápice obcordado, alas reduzidas, 2-3 $\mathrm{mm}$ larg., secas, esparsamente lepidotas, transversalmente estriadas, estrias muito próximas entre si; pedicelo frutífero 1,5-2,5 mm compr. Semente 1, 1,5-1,8×3-4 mm, estreito-elipsóide, sulcada longitudinalmente, testa coriácea, enrugada, castanho-clara, cotilédones foliáceos.

Combretum laxum é uma espécie neotropical, exclusiva nas Américas, com distribuição confirmada no México, Panamá, Guatemala, Honduras, Antilhas, Suriname, Guianas, Venezuela, Colômbia, Equador, Bolívia, Peru, Paraguai, Argentina e Brasil (Exell 1953). De acordo com Loiola \& Sales (1996), apresenta ampla distribuição no Brasil, ocorrendo nas regiões Norte (Amapá, Amazonas, Pará, Rondônia, Roraima), Nordeste (Bahia, Ceará, Maranhão, Paraíba, Pernambuco, Piauí), Centro-Oeste (Distrito Federal, Goiás, Mato Grosso, Mato Grosso do Sul), Sudeste (Minas Gerais, Rio de Janeiro, São Paulo) e Sul (Paraná). Na Paraíba, a espécie foi encontrada em remanescentes de Floresta Atlântica e em uma área de Caatinga.

Material examinado: BRASIL. Paraíba: João Pessoa, Gramame, IV/1993, fr., Moura 985 (JPB); Distrito Industrial, I/1995, fr., Moura 1473 (JPB); Distrito Industrial, margem do rio Mumbaba, X/1994, fl., Moura s.n. (JPB 22567); Pombal, XII/1955, fr., Carneiro s.n. (JPB 2894).

2.7. Combretum leprosum Mart., Flora 24(2): 1. 1841. Fig. 20-22

Arbustos escandentes ou lianas, 2-3 m de alt., 


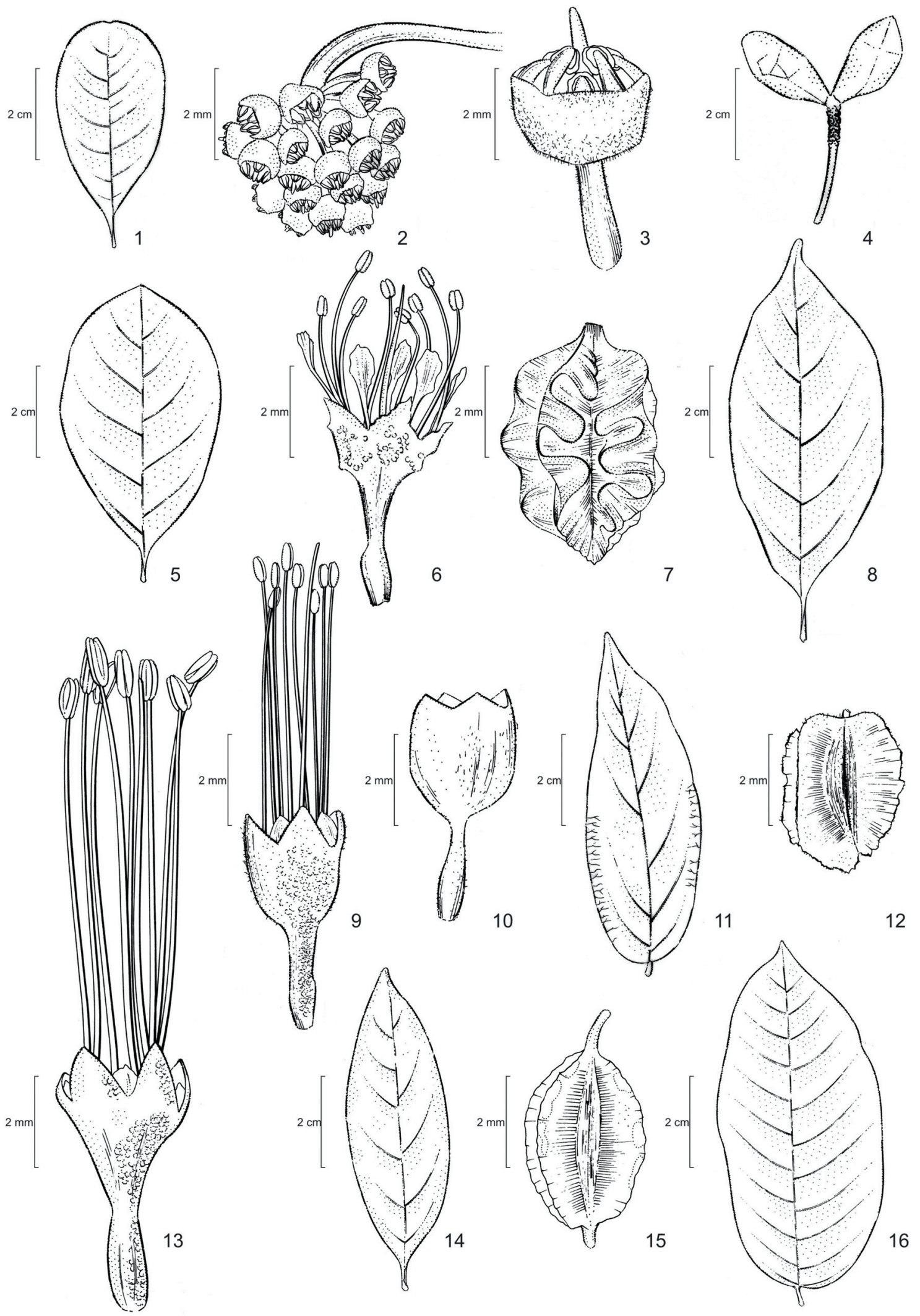

Figuras 1-16. 1-4. Buchenavia tetraphylla (Aubl.) R.A. Howard (Neto 216): 1. Folha. 2. Inflorescência. 3. Flor. 4. Fruto. 5-7. Combretum duarteanum Cambess. (Coelho et al. s.n.): 5. Folha. 6. Flor. 7. Fruto. 8-9 Combretum fruticosum (Loefl.) Stuntz (Agra 146): 8. Folha. 9. Flor. 10. Combretum glaucocarpum Mart. (Barbosa et al. 2067): 10. Flor. 11-12. Combretum hilarianum D. Dietr. (Lima et al. 124): 11. Folha. 12. Fruto. 13-15. Combretum lanceolatum Pohl ex Eichl. (Agra 285): 13. Flor. 14. Folha. 15. Fruto. 16. Combretum laxum Jacq. (Moura 985): 16. Folha. 
indumento lepidoto, com tricomas escamosos, brilhantes, hialinos ou esbranquiçados, revestindo caule, ramos, folhas, botões, flores e frutos. Folhas opostas, pecioladas; pecíolo 5-12 $\mathrm{mm}$ compr.; lâmina 5,3-13×2,8-6 cm, cartácea a subcoriácea, elíptica, largoelíptica a arredondada, base aguda a arredondada, ápice agudo a acuminado, levemente discolor a concolor; opaca em ambas as faces; nervuras proeminentes abaxialmente. Inflorescências em panículas de racemos, densifloras, congestas, terminais e axilares; raque principal 23-100 cm compr.; raque dos racemos 2-7 cm compr.; botões 4-5 mm compr., clavados. Flores subsésseis, 9-10 mm compr.; bractéola 1, 1,5-2 mm compr., linear, persistente, densamente lepidota; hipanto inferior 1,5-2×0,5-0,7 mm, fusiforme, densamente lepidoto; hipanto superior 3,5-4,5×3-4 mm, alongado-campanulado, esparsamente lepidoto, esverdeado; lobos do cálice 1,5-2×1,5-2 mm, triangulares; pétalas 4 , 1-1,5×1-1,5 mm, maiores que os lobos do cálice, glabras, arredondadas a oblatas, ápice obcordado, cremes na antese e amarelas na maturidade. Estames 8, exsertos; filetes do verticilo interno $3,5-4 \mathrm{~mm}$ compr., filetes do verticilo externo 4,5-5 $\mathrm{mm}$ compr.; anteras 0,4-0,5×0,4-0,5 mm, elípticas, amarelas. Disco nectarífero desenvolvido, sem margens livres, densamente viloso na altura da inserção dos filetes; estilete 4-6 mm compr. Fruto betulóide, 4-alado, 1,8-2,4x 1,8-2,1 cm, largamente elíptico, esparsamente lepidoto nas alas, mais compacto na região central; alas 5-7 mm larg., secas, esparsamente lepidotas, transversal e estreitamente estriadas; pedicelo frutífero 1-2 mm compr., levemente sulcado. Semente 1, 0,9-1,2× 0,4-0,5 mm, oval, 4-sulcada, acompanhando a forma do fruto, testa coriácea, branco-esverdeada no fruto imaturo, castanho-escura no fruto maduro, cotilédones foliáceos.

Nomes populares: mofumbo e mufumbo.

Espécie neotropical com distribuição exclusiva na América do Sul, com registro para a Bolívia, Paraguai e Brasil (Exell, 1953). No Brasil, de acordo com Loiola \& Sales (1996), as populações de C. leprosum ocorrem principalmente nas regiões Nordeste (Ceará, Maranhão, Pernambuco, Piauí e Rio Grande do Norte), norte (Pará), Centro-Oeste (Goiás, Mato Grosso e Mato Grosso do Sul) e Sudeste (Minas Gerais). Também foi citada para o Rio de Janeiro por Exell (1953). Na Paraíba, a espécie foi referida por Agra et al. (2004) para uma área de Mata Serrana, no Pico do Jabre, e tem sido encontrada na Caatinga, onde é abundante, principalmente na microrregião do Cariri Paraibano, ocorrendo em elevações acima de $500 \mathrm{~m}$ de atitude.

Material examinado selecionado: BRASIL. Paraíba: Sem local preciso, I/1920, fl., Luetzelburg 12472 (NY); Boaventura, X/1997, fr., Barbosa 1604 (JPB);
Cajazeiras, V/1992, fl., Moura \& Moreira 13 (JPB); Coremas, V/1984, fl., Sales 34 (PEUFR); Itaporanga, Serra Água Branca, I/1994, fl., Agra et al. 2463 (JPB); I/1994, fl., A gra et al. 2538 (JPB); Juazeirinho, IX/1941, fr., Maia s.n. (JPB 282); III/1993, fl. fr., Agra \& G. Silva 1594, 1620 (JPB, NY); VI/1995, fl., Agra et al. 3389 (JPB); VIII/1984, fr., Ataíde et al. 01 (PEUFR); Patos, VI/1984, fl., Agra 464 (JPB); Patos, Campo Clarindo Gouveia, I/1943, fl., Xavier s.n. (JPB1156); estrada Patos-Pombal, IV/1972, fl., Correa s.n. (JPB 3193); Pombal, IX/1952, fl., Carneiro s.n. (JPB 1665); Santa Luzia, III/2006, fl., Agra et al. 6559 (JPB); São João do Cariri, Estação Experimental, III/1994, fl., Aguiar 76 (JPB); IX/1994, fl., Aguiar 107 (JPB); Estação

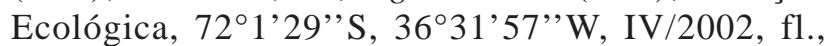
Barbosa et al. 2334 (JPB); 07²1'29"'S, 36 31'57”'W, IV/2002, fl., Barbosa et al. 2336 (JPB); São João do Cariri, fazenda Experimental, V/1987, fl., Félix \& Dorneles 666 (EAN); São José do Bonfim, III/2002, fl., Marinho et al. 6 (JPB); VI/2003, fr., Veloso \& Aires 26 (JPB); São José dos Cordeiros, RPPN - Fazenda Almas, trilha da Pedra da Bola, V/2003, fr., Lima et al. 101 (JPB); São José de Piranhas, Serra do Vital, IX/2001, fr., Barbosa et al. 2174 (JPB); Serra Branca, base da pedra, II/2002, fl., Barbosa et al. 2198 (JPB); base da pedra, III/2002, fl., Agra et al. 5697 (JPB); base da pedra, 26/IV/2006, fl., Agra et al. 6731 (JPB); Soledade, margem do açude, III/2000, fl., Barbosa et al. 1990 (JPB); III/1987, fl., Sales et al. 51 (PEUFR); Sousa, Serrote, VII/1982, fr., Sousa et al. 1251 (JPB); Faz. Jangada,VI/1993, fl., fr., Gadelha Neto 78 (JPB); Faz. Lamarão, IV/1995, fl., Gadelha Neto \& Moreira 253 (JPB); Sítio Lamarão, IV/1996, fl., H. Moreira 34 (JPB); VI/1996, Moreira 50 (JPB); Vale dos Dinossauros, I/1998, fr., Gadelha Neto 375 (JPB); Vale dos Dinossauros, III/2000, fl., Gadelha Neto 566 (JPB); Vale dos Dinossauros, III/2000, fl., Gadelha Neto 569 (JPB); Sousa, entre Souza e Antenor Navarro, IV/1982, fl., fr., Sousa et al. 1209 (JPB); em local não determinado, I/1935, fl., Zenaide s.n. (SP).

2.8. Combretum pisonioides Taub., Bot. Jahrb. Syst. 15(34): 10. 1892.

Árvores ou arbustos, eretos, 2-5m alt.; indumento lepidoto, brilhante, com tricomas hialinos ou ferrugíneos, revestindo o caule, ramos, folhas, botões, flores e frutos. Folhas opostas, curto-pecioladas; pecíolo 3-4 mm compr.; lâmina foliar 2-4,3×1,3-2,8 cm, elíptica a largoelíptica, base aguda, ápice acuminado, membranácea, discolor, face adaxial verde-escura, face abaxial verdeclara; venação proeminente na face abaxial e impressa na adaxial. Inflorescências em capítulos paucifloros, laxos, terminais e axilares; raque dos racemos 4-7 mm compr.; botões 2-4 mm compr., turbinados. Flores 
monoclinas, 6-7 mm compr.; bractéola 1, 1-2 mm compr., estreito-linear a linear, caduca ou persistente, ápice constricto; hipanto superior 2-2,5×2,5-3 mm, largo infundibuliforme na base, largo-cupuliforme no ápice, esverdeado; hipanto inferior 1,5-1,8×0,5-0,6 mm, elipsóide, densamente lepidoto; pétalas 4, com 0,8-1×0,4-0,5 mm, glabras, brancas, espatuladas, ápice agudo, maiores que os lobos do cálice. Estames 8, exsertos; filetes do verticilo interno 3-3,5 mm compr., filetes do verticilo externo $3,5-4 \mathrm{~mm}$ compr., brancos; anteras 0,4-0,5×0,4-0,5 mm, elípticas, alaranjadas. Disco nectarífero com margem livre, viloso à altura da inserção dos filetes. Estilete 2,5-3,5 mm compr., filiforme, menor ou do mesmo tamanho dos estames; estigma punctiforme, inconspícuo. Fruto 4-alado, 1,1-1,3(2,4)× 0,4-0,5 cm, orbicular ou elipsóide; alas desenvolvidas, 4-4,5(7) $\mathrm{mm}$, delgadas, secas, esparsamente lepidotas, diminutamente estriadas no sentido transversal; pedicelo frutífero 1,5-2 mm compr. Semente 1, 0,9-1,2× 0,4-0,5 mm, oval, 4-sulcada, acompanhando a forma do fruto; testa coriácea, branco-esverdeada no fruto jovem, marrom no fruto maduro, cotilédones convolutos, verdes e lepidotos.

Espécie neotropical, exclusiva da flora brasileira, com distribuição no Nordeste, somente encontrada nos Estados da Bahia, Ceará, Maranhão, Paraíba, Pernambuco e Piauí, habitando preferencialmente os ambientes quentes e secos, característicos da caatinga, em solos pedregosos, arenosos ou areno-argilosos, podendo ser encontrada também em zonas de transição caatinga/cerrado no Piauí e Maranhão (Loiola \& Sales, 1996). Na Paraíba, a espécie foi coletada em uma área de Brejos de Altitude, agreste e Caatinga, ocorrendo acima de $500 \mathrm{~m}$ de altitude.

Material selecionado: BRASIL. Paraíba: Areia, II/1959, fl., Moraes s.n. (EAN 2039); Esperança, IX/1958, fl., Moraes s.n. (EAN 1884); Itaporanga, 37 $\mathrm{km}$ depois de Itaporanga, em direção à Conceição, XI/1971, fl., Andrade-Lima et al. 1087 (PEUFR).

3. Conocarpus L., Sp. Pl. 1: 176-177. 1753.

3.1. Conocarpus erectus L., Sp. Pl. 1: 176. 1753. Fig. 23-26

Arbustos ou árvores eretas, 3-6 m alt., sem pneumatóforos; ramos cilíndricos, cinéreos a enegrecidos na maturidade. Folhas alternas, duas glândulas no pecíolo ou na base da lâmina; pecíolo 0,6-1,5 cm compr., alado; lâmina 7,5-11×4,5-6,5 cm, elíptica a obelíptica, ápice agudo ou arredondado, base aguda decurrente no pecíolo, brilhante, coriácea, argênteo-serícea quando jovem, glabrescente ou glabra na planta adulta, fóveas (domácias) conspícuas nas axilas das nervuras secundárias na face abaxial.
Inflorescências em capítulos globosos, axilares ou terminais, $2-3 \mathrm{~cm}$ diâm.; pedúnculos $0,7-1,6(-2) \mathrm{cm}$ compr., argênteos, seríceos; bractéola 1 , ca. $1 \mathrm{~mm}$ compr., cimbiforme, serícea na face externa, caduca. Flores monoclinas e estaminadas, $0,5-0,7(-0,8) \mathrm{cm}$ compr., pentâmeras, esverdeadas a alvo-amareladas, fragrantes; hipanto inferior 0,4-0,6 mm compr., densopubescentes; hipanto superior $0,9-1,5 \times 1-1,2 \mathrm{~mm}$ compr., campanulado, esparso-pubescente, com 5 lobos do cálice, 0,2-0,3 $\mathrm{mm}$, triangulares; pétalas ausentes. Estames 8, exsertos; filetes filiformes, subulados, maiores nas flores estaminadas, $1,5-1,8 \mathrm{~mm}$ compr., mais curtos nas flores femininas, $0,8-1 \mathrm{~mm}$; anteras ca. $0,3 \times 0,2 \mathrm{~mm}$, cordadas, apiculadas, versáteis, alvas. Disco nectarífero 5-glanduloso, carnoso, viloso à altura da inserção dos filetes; estilete ca. (1-)1,3-2 mm compr. Infrutescências em capítulos globosos a elipsóides, estrobiliformes 1-1,5×0,9-1,3 cm, secos, intumescidos e escuros na maturidade. Frutos 2-3×1-1,2 mm, 2-alados, encurvados, aplanados e coroados pelo hipanto superior até a maturação, verdeclaros a marrons. Semente 1, oboval a triangular, 1,7-2,5×0,7-1,2 mm, não acompanhando a forma do fruto, testa coriácea, castanho-esverdeada no fruto jovem, castanho-escura no fruto maduro, cotilédones convolutos, castanho-esverdeados.

Nomes populares: mangue-de-botão, mangue-bola e sapateira.

De acordo com Stace (2001), Conocarpus erectus é freqüente em mangues pantanosos e terrenos arenosos ao longo das costas pacífica e atlântica, em altitudes de 0-30 m, com floração e frutificação ocorrendo durante a maior parte do ano. A espécie é encontrada do México ao norte do Peru, Brasil, Antilhas e África ocidental. Na Paraíba foi encontrada em praticamente todo o litoral do Estado, crescendo no seu habitat característico de mangue, estendendo-se aos ambientes arenosos, como pode ser observado nas praias de Tabatinga, Coqueirinho, Carapibus e Tambaba.

Material selecionado: BRASIL. Paraíba: Cabedelo, III/1984, fl., fr., Silva et al. 1085 (JPB); III/1984, fl., fr., Silva et al. 1085 (JPB); Cabedelo-João Pessoa, II/1972, fl., Xavier s.n. (JPB 3234); Restinga de Intermares, III/1996, fl., fr., Moura 136 (JPB); Praia de Intermares, mangue próximo à praia, 15/XI/2005, fl., Rocha et al. 1381 (JPB); Ilha da restinga, 13/IV/1992, fr., Felix et al. 4795 (EAN); Conde, Tapitinga, XI/1991, fl., fr., Moura 745 (JPB); Conde, Praia de Jacumã, mangue na entrada para a praia, 27/IV/2006, fl., Agra et al. 6884 (JPB); Tambaba, 07²2'5"S, 3459'5" W, VIII/2003, fl., fr., Thomas 13628 \& Barbosa (JPB); João Pessoa, mangue do Rio Gramame, próximo à ponte, 7¹4'03”'S, 3450'34'W, 15/XI/2005, fl., Rocha 1376 


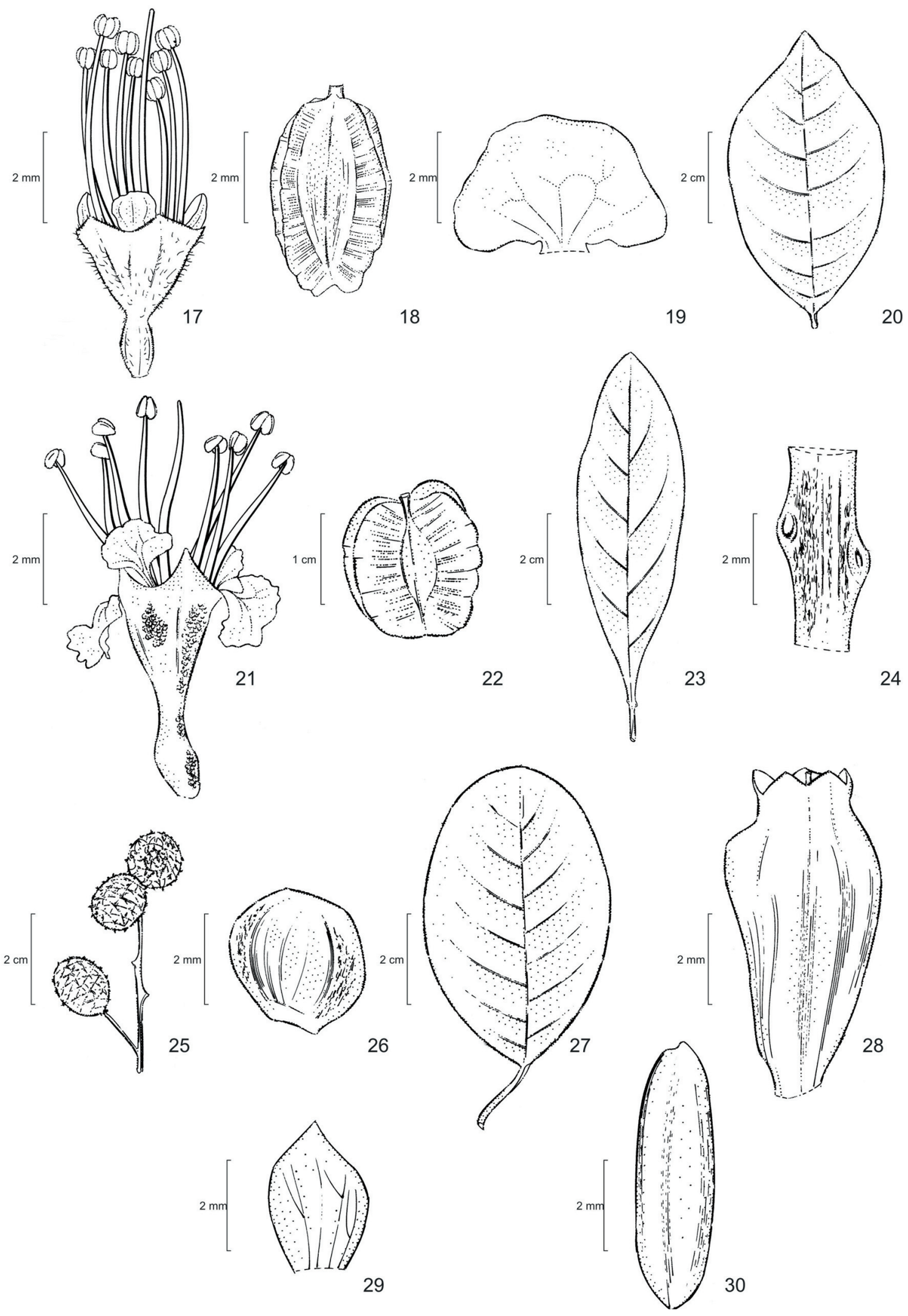

Figuras 17-30. 17-19. Combretum laxum Jacq. (Moura 985): Flor. 18. Fruto. 19. Pétala isolada. 20-22. Combretum leprosum Mart. (Agra et al. 2463): 20. Folha. 21. Flor. 22. Fruto. 23-26. Conocarpus erectus L. (Thomas \& Barbosa 13628): 23. Folha. 24. Detalhe das glândulas do pecíolo. 25. Inflorescência. 26. Bractéola. 27-30. Laguncularia racemosa (L.) C.F. Gaertn. (César 246): 27. Folha. 28. Fruto. 29. Detalhe da porção interna da sépala. 30. Semente. 
(JPB); Praia do Sol, IX/1987, fl., fr., Miranda s.n. (JPB 7369); Rio Grau, IX/1997, fl., fr., Alves 04 (JPB); mangue de Jacarapé, IV/1990, fl., fr., Moura 417 (JPB); Laguna de Jacarapé, IX/1997, fl., fr., Alves 13 (JPB); Praia de Jacarapé, 07 $11^{\prime} 44^{\prime \prime} S$, 3447'47' W, fl., 15/IX/2005, Rocha 1370, 1376 (JPB); Mamanguape, Barra de Mamanguape, XI/1989, fl., Félix \& Sousa s.n. (JPB 8090); 29/XI/2006, fr., Félix \& Mata 11365 (EAN).

4. Laguncularia C.F. Gaertn., Suppl. Carp. 3: 209. 1807.

4.1. Laguncularia racemosa (L.) C. F. Gaertn., Suppl. Carp. 3: 209, t. 217. 1807.

Fig. 27-30

Árvores 3-6 m alt., com raízes adventícias e freqüentemente com pneumatóforos; caule e ramos avermelhados e quadrangulares quando jovens, cilíndricos e enegrecidos na planta adulta. Folhas opostas, longo-pecioladas; pecíolo 1,4-1,7 cm compr., avermelhado a marrom, 2 glândulas na porção distal; lâmina 7,5-11×4,5-6,5 cm, elíptica a oblongo-elíptica, ápice e base obtusa a rotunda, glabra, glândula basal na face abaxial, castanho-esverdeada em ambas as faces, venação abaxial proeminente. Inflorescências em espigas axilares ou terminais, ou racemos de espigas, 5-14(-16) cm compr., laxas, paucifloras; pedúnculo 2-9 cm compr.; raques seríceas, amarelas a ferrugíneas, 3-7 cm compr.; bractéola 1, 1,5-2 mm compr., cimbiforme, puberulenta. Flores alvas a cremes, pubérulas; as masculinas 2-3 $\mathrm{mm}$ compr., incluindo o cálice; as femininas ou bissexuais 4,5-5 $\mathrm{mm}$ compr., gradualmente alargando-se no fruto; hipanto inferior 1-2×1-2 mm, campanulado, 2 bractéolas laterais soldadas à base do hipanto; hipanto superior 1-2×3-4 mm compr., cupuliforme; 5 lobos do cálice pubescentes, 1-1,2×0,7-0,9 mm; sépalas espatuladas a suborbiculares, caducas. Estames 10, insertos, filetes $0,5-0,7 \mathrm{~mm}$ compr.; anteras ca. 4-4 mm, cordiformes, alvas. Fruto nucóide, 1-1,3×0,4-0,5 cm, levemente comprimido, longitudinalmente costado, obovóide, constricto na porção superior, coronado pelos lobos do cálice. Semente 1, oblonga, 0,9-1,1×0,4-0,5 cm; testa coriácea, castanho-esverdeada no fruto jovem, negra no fruto maduro, cotilédones convolutos, castanho-esverdeados.

Nomes populares: mangue-branco, mangueamarelo, mangue-manso e mangue-sapateiro.

De acordo com Stace (2001), é uma espécie característica de mangues pantanosos ao longo das costas do Pacífico e do Atlântico, ocorrendo em altitudes de 0-10 m, com distribuição no México, Peru, Antilhas e oeste da África, com floração e frutificação ocorrendo a maior parte do ano. Na Paraíba, a espécie foi encontrada praticamente em todo o litoral, em áreas de manguezais, desde o litoral norte, em Barra de Camaratuba, até as praias ao sul do Estado, como Pitimbu.

Material selecionado: BRASIL. Paraíba: Bayeux, porto da Oficina, II/2002, fr., César 246 (JPB); Cabedelo-João Pessoa, II/1972, fr., Xavier s.n. (JPB 3272); Cabedelo, Ilha da Restinga, XI/1980, fl., Silva s.n. (JPB 4567); IV/1992, fr., Félix et al. 4809 (EAN); próximo à Mata do Amém, XII/1981, fl. fr., Xavier s.n. (JPB 5557); João Pessoa, mangue do rio Sanhauá, XI/1971, fl., Carvalheira s.n. (JPB 3020); Mangue de Jacarapé, IV/1988, fr., Moura 359 (JPB); IV/1990, fl., Moura 419 (JPB); Baixo Roger, III/1990, fl., Oliveira 09 (JPB); Laguna de Jacarapé, IX/1997, fl., Alves 12 (JPB); Mamanguape, Barra de Mamanguape, II/1989, fr., Félix \& Santana s.n. (JPB 8041).

\section{Agradecimentos}

Ao Conselho Nacional de Desenvolvimento Cientifico e Tecnológico (CNPq) e à Universidade Estadual de Santa Cruz (UESC), pelas bolsas concedidas a M. F. Agra e E. A. Rocha, respectivamente. Aos curadores dos herbários EAN, IPA, UFRPE, em especial a Dra. Maria Regina V. Barbosa, curadora do herbário JPB, pelo livre acesso à coleção; ao Dr. Jnanabrata Bhattacharyya pela revisão do abstract; a Kiriaki Nurit e Dulce Gonçalves Oliveira, pelo apoio técnico.

\section{Referências bibliográficas}

Agra, M.F. 1996. Plantas da medicina popular dos Cariris Velhos, Paraíba, Brasil: espécies mais comuns. João Pessoa, Editora União.

Agra, M.F.; Barbosa, M.R.V. \& Stevens, W.D. 2004. Levantamento Florístico Preliminar do Pico do Jabre, Paraíba, Brasil. Pp. 123-138. In: K.C. Porto, J.J.P. Cabral \& M. Tabarelli (orgs.). Brejos de Altitude em Pernambuco e Paraíba: História Natural, Ecologia e Conservação. Brasília, Ministério do Meio Ambiente (Série Biodiversidade, 9).

Agra M.F.; Baracho G.S.; Nurit K.; Basílio I.J.L.D. \& Coelho V.P.M. 2007. Medicinal and poisonous diversity of the flora of "Cariri Paraibano", Brazil. Journal of Ethnopharmacology 111: 383-395.

Andrade-Lima \& Rocha, G.N. 1971. Observações preliminares sobre a Mata do Buraquinho, João Pessoa. Paraíba. Anais Instituto de Ciências Biológicas 1: 47-61.

APG II. 2003. An update of the Angiosperms Phylogeny Group classification for the orders and families of flowering plants. Botanical Journal of the Linnean Society 141: 399-436.

Baba-Moussa, F.; Akpagana, F.K. \& Bouchet, P. 1999. Antifungal activities of seven West African Combretaceae used in traditional medicine. Journal of Ethnopharmacology 66: 335-338.

Barbosa, M.R.V.; Agra, M.F.; Sampaio, E.V.S.B.; Cunha, J.P. \& Andrade, L.A. 2004. Diversidade Florística na Mata do PauFerro. Pp. 111-122. In: K.C. Porto, J.J.P. Cabral \& M. Tabarelli (Ufrgs.), Brejos de Altitude em Pernambuco e Paraíba: História Natural, Ecologia e Conservação. Brasília: Ministério do Meio Ambiente (Série Biodiversidade, 9).

Barroso, G.M.; Morim, M.P.; Peixoto, A.L. \& Ichaso, C.L.F. 1999 Frutos e Sementes - Morfologia Aplicada á Sistemática de Dicotiledôneas. Viçosa, Editora UFV.

Bentham G. \& Hooker, J.D. 1867. Genera plantarum, v.1. Reeve, 
London, Pp. 683-690.

Brandis, D. 1898. Combretaceae. Pp. 115. In: A. Engler \& K.A.E. Prantl (eds.). Natürlichen Pflanzenfamilien, v.3. Engelmann, Leipzig.

Braga, R. 1960. Plantas do nordeste, especialmente do Ceará. $2^{a}$ ed. Fortaleza, Imprensa Oficial.

Brummitt, R.K. \& Powell, C.E. 1992. Authors of plant names. Kew, Royal Botanic Gardens.

Cabral, S. \& Agra, M.F. 1999. Flora da Paraíba: Olacaceae Mirb. ex DC. Revista Nordestina Biologia 13: 1-11.

Carvalho, F.A.F. \& Carvalho, M.G.F. 1985. Vegetação. Pp. 34-43. In: Governo do Estado da Paraíba (ed.). Atlas Geográfico do Estado da Paraíba. João Pessoa, Secretaria da Educação, Ed. Grafset.

Coelho, V.P.; Agra, M.F. \& Baracho, G.S. 2008. Flora da Paraíba, Brasil: Polygala. Acta Botanica Brasilica 22: 225-229.

Conti, E.; Litt, A. \& Sytsma, K.J. 1996. Circumscription of Myrtales and their relationships to other rosids: evidence from $r b c L$ sequence data. American Journal of Botany 83: 221-233

Conti, E.; Litt, A.; Wilson, P.G.; Graham, S.A.; Briggs, B.G.; Johnson, L.A.S. \& Sytsma, K.J. 1997. Interfamilial Relationships in Myrtales: Molecular Phylogeny and Patterns of Morphological Evolution. Systematic Botany 22: 629-647.

Cronquist, A. 1988. The evolution and classification of flowering plants. 2a. ed. New York, New York Botanical Garden.

Dalhgren, R.M.T. \& Thorne, R.F. 1984. The order Myrtales: circumscription, variation and relationship. Annals of the Missouri Botanical Garden 71: 633-699.

Eichler, A.G. 1867. Combretaceae. In: C.F.P. Martius; A.W. Eichler \& I. Urban (eds.). Flora Brasiliensis 14: 77-128.

Engler, A. \& Diels, L. 1899. Monographieen Afrikanischer Pflanzenfamilien und Gattungen 3: Combretum. Leipzig, Verland von Wilhelm Engelmann.

Exell, A.W. 1931. The genera of Combretaceae. Journal of Botany 69: $113-128$

Exell, A.W. 1953. The Combretum species of the new world. Botanical Journal of the Linnean Society 55: 130-141.

Exell, A.W. \& Stace, C.A. 1966. Revision of the Combretaceae. Boletim Sociedade Broteriana 40: 5-25.

Fawcett, W. \& Rendle, A.B. 1925. Notes on Jamaica plants: Combretum. Journal of Botany 63: 114-115.

Férrea, G.; Canessa, A.; Sampietro, F.; Cruniani, M.; Romussi, G. \& Bassetti, D. 1993. In vitro activity of a Combretum micranthum extract against herpes simplex virus types 1 and 2. Antiviral Research 21: 317-325.

Fyhrquist, P.; Mwasumbi, L.; Haeggström, C.A.; Vuorela, H.; Hiltunen, R. \& Vuorela, P. 2002. Ethnobotanical and antimicrobial investigation on some species of Terminalia and Combretum (Combretaceae) growing in Tanzânia. Journal of Ethnopharmacology 79: 169-177.

Giulietti, A.M.; Harley, R.M.; Queiroz, L.P.; Barbosa, M.R.V.; Bocage Neta, A.L.; Figueiredo, M.A. 2002. Espécies endêmicas da caatinga. Pp. 103-118. In: E.V.S.B. Sampaio; A.M. Giulietti; J. Virgínio \& C.F.L. Gamarra-Rojas (eds.). Vegetação e Flora da Caatinga. Recife, Associação Plantas do Nordeste/ Centro
Nordestino de Informações sobre Plantas.

Holmgren, P.K.; Holmgren, N.H. \& Barnet, L.C. 1990. Index Herbariorum, Part I. The Herbaria of the World. 8 ed. New York, The New York Botanical Garden Press.

Loiola, M.I.B. \& Sales, M.F. 1996. Estudos taxonômicos do gênero Combretum Loefl. (Combretaceae R. Br.) em Pernambuco - Brasil. Arquivos do Jardim Botânico do Rio de Janeiro 34: 173-190.

Loiola, M.I.B. 1998. Combretaceae. Pp. 58. In: M.F. Sales; S.J. Mayo \& M.J.N. Rodal (eds.). Plantas Vasculares das Florestas Serranas de Pernambuco: um checlist da Flora Ameaçada dos Brejos de Altitude, Pernambuco, Brasil. Recife, Universidade Federal Rural de Pernambuco.

Loiola, M.I.B.; Agra, M.F.; Baracho, G.S. \& Queiroz, R.T. 2007. Flora da Paraíba, Brasil: Erythroxylaceae. Acta Botanica Brasilica 21: $473-487$.

Marquete, N.F.S. 1995. Combretum Loefling Brasil- Sudeste (Combretaceae). Arquivos do Jardim Botânico do Rio de Janeiro 33: 55-107.

Marquete, N.F.S.; Teixeira, J. \& Valente, M.C. 2003. Terminalia (Combretaceae) na região sudeste do Brasil. Bradea 9: 99-123.

Marquete, N.F.S. \& Valente, N.M. 2006. Flora da Reserva Ducke, Amazonas, Brasil: Combretaceae. Rodriguésia 56: 131-140.

Nurit, K.; Agra, M.F.; Basílio, I.J.L.D. \& Baracho, G.S. 2005. Flora da Paraíba, Brasil: Loganiaceae. Acta Botanica Brasilica 19: 407-416.

Pontes, A.F.; Barbosa, M.R. \& Maas, J.M. 2004. Flora Paraibana: Annonaceae Juss. Rodriguésia 18: 281-293.

Pontes, R.A.S. \& Agra, M.F. 2005. Flora da Paraíba, Brasil: Tillandsia L. (Bromeliaceae). Rodriguésia 57: 47-61.

Rocha, E.A. \& Agra, M.F. 2001. Lista anotada das Lamiaceae da Paraíba, Brasil. Revista Nordestina de Biologia 15: 71-75.

Stace, C.A. 1965. The significance of the leaf epidermis in the taxonomy of the Combretaceae, I. A. General review of tribal, generic and specific characters. Botanical Journal of Linnean Society 59: 229-252

Stace, C.A. 1968. A revision of the genus Thiloa (Combretaceae). Bulletin of the Torrey Botanical Club 95: 156-165.

Stace, C.A. 2001. Combretaceae. In: D.W. Stevens; C. Ulhoa-Ulhoa, A. Pool \& O.M. Montiel (eds.). Flora de Nicaragua. Monographs in Systematic Botany 85 .

Stace, C.A. 2004. Combretaceae. Pp. 110-111, fig. 55, pl 15. In: N. Smith; S.A. Mori; A. Henderson; D.W. Stevenson \& S.V. Heald (eds.). Flowering Plants of the Neotropics. United Kingdom, The New York Botanical Garden. Princenton University Press.

Stearn, W.T. 1992. Botanical Latin. 4 ed. David \& Charles Book, Redwood Press. England Ltd.

Tahktajan, A. 1997. Diversity and Classification of Flowering Plants. New York, Columbia University Press.

Tan, F.; Shi, S.; Zhong, Y.; Gong, X. \& Wang, Y. 2002. Phylogenetic relationships of Combretoideae (Combretaceae) inferred from plastid, nuclear gene and spacer sequences. Journal of Plant Research 115: 475-481.

Weaver, P.L. 1991. Buchenavia capitata (Vahl.) Eichler: Granadillo. SO-ITF-SM-43, Department of Agriculture, Forest Service, Southern Forest Experiment Station, New Orleans.

Zappi, D.C. 1995. Combretaceae. Pp. 174-175. In: B.L. Stannard (ed.). Flora of the Pico das Almas, Chapada Diamantina, Bahia, Brazil. Kew, Royal Botanic Gardens. 